\title{
The women of castanha do Alto Cajari: empowerment by the solidarity economy
}

\author{
Kátia Paulino dos Santos
}

${ }^{I}$ State University of Amapa, Macapa, Amapa, Brazil.

\begin{abstract}
This study aims to understand the operation dynamic of solidarity economy and the empowerment process generated by it, by analyzing the Association of Agricultural-Extractivist Women of Alto Cajari, located in the southernmost of the State of Amapa, northernmost of Brazil, which works on processing Brazilian nut. As a method, we used the cost-effectiveness analysis and qualitative research, aiming to measure the main advances and challenges imposed on the segment. This study identified the need for restructuring the management formats of promotion policies by government agencies, which should operate in a harmonious and articulated way; however, they conversely act separately, without effective communication among them, impairing the quality and the quantity of the services offered.
\end{abstract}

Keywords: Solidarity economy. Empowerment. Alto Cajari Agricultural-Extractive Women Association.

São Paulo. Vol. 24, 2021

Original Article

DOI: http://dx.doi.org/10.1590/1809-4422asoc20200066r1vu2021L4AO 


\section{Introdution}

Solidarity economy is inserted in a complex and dynamic context, since it emerges as a possibility within a consolidated model, with exposed frailties and that tries to derail any attempt to alter its logic. The constant crises and disruptions demonstrated by the capitalist economy increasingly urge for the search for alternatives, be it on the part of the organized civil society or on the part of the State, as one that systematizes rules and political actions.

The persistence of hunger on the planet, the inequality indicators, the high concentration of income by a minority, the stunning numbers of unemployment and precarious jobs are factors that reveal the collapse of the capitalist system, mainly in peripheral countries, also revealing the need to seek for alternatives to its excluding and perverse logic.

A possibility that has gained momentum in recent decades is solidarity economy; according to Paul Singer (2007), it is a production mode characterized by equality. By the equality of rights, the means of production are the collective assets of those working with them; this is its central characteristic. The solidarity economy enterprises are managed by the workers themselves, collectively and democratically.

Solidarity economy has increased in Brazil from different perspectives. From the social viewpoint, a growth is perceived regarding the number of enterprises composing the sector and also a higher enlightenment regarding the theoretical and ideological contexts in which they are inserted, since a number of people formulated the proposal without exactly knowing the meaning, or the differences in nuances in comparison to the traditional capitalist economy. The past decade presented a significant intensification of public policies to promote solidarity economy, made possible by the establishment of the National Secretariat of Solidarity Economy (SENAES), in 2003.

After the establishment of SENAES, it was possible to implement a set of actions that aimed at promoting and strengthening solidarity economy initiatives, as forms of associated work organization. Over the years, the Secretariat was consolidated, contributing to expanding the institutional mission of the Ministry, that of promoting associated work along with forms of wage labor.

In Michel Temer's term of office, started in 2016, SENAES was downgraded to a Subsecretariat. In Bolsonaro's term of office, SENAES ceased to exist and was transformed into a department in the Ministry of Citizenship by Provisional Measure number 870 of 2019, enforced in January 2020.

The major objective of this paper is to analyze the management form of the solidarity economy policy in the State of Amapá and its contributions to the women empowerment process, by means of a study into the Association of Agricultural-Extractivist Women of Alto Cajari (AMAC).

This study has a qualitative character, since it is concerned with aspects of reality that cannot be quantified, focusing on understanding and explaining the dynamic of social relationships. As a strategy to develop the investigation, the option was for conducting a case study into AMAC. The result section presents the set of information collected 
by the study through a cost-effectiveness analysis, employing the in loco observation technique, document analysis and performance of interviews with the president and associates of the enterprise.

The paper is structured into three sections. The first one deals with solidarity economy in Brazil, presenting a brief history and its differentials. In the second, empowerment is discussed, focusing on women empowerment, in the perception of different authors. The last section presents the results of the case study, reporting the major advances and challenges of AMAC, the promotion policies and their contributions to the empowerment process of the women associated in the perception of the president of the association and its associates.

\section{Solidarity economy in Brazil: purposes and differentials}

Solidarity Economy emerges as an economic and social alternative to the capitalist economy and its conflicts, with a significantly innovative proposal and with characteristics that strongly confront the capitalist methodology, since it is founded on values such as solidarity, sustainability and self-management. Due to its differentials, solidarity economy has advanced as a research object in different countries in the world, currently counting on a significant bibliographic collection.

In Brazil, the upward trajectory of solidarity economy as a State policy is connected to the trajectory of the Partido dos Trabalhadores' (PT - Workers' Party) Government, started in 2003 and ended in 2016.

In A Economia Solidária na América Latina (Solidarity Economy in Latin America), Singer (2012) contextualizes the scenario of the emergence of SENAES, stressing that the discussion on Solidarity Economy in the Workers' Party (PT) started around 1999/2000. At that time, a national PT congress was held in Belo Horizonte, and at that congress, the problem of the meaning of socialism in the post Berlin wall times clearly appeared; that is, in the times post-1989, when the regimes of the so-called real socialism were practically brought down. These regimes were all overthrown and replaced with democratic regimes and the economic system went back to being or started to be capitalist.

Faced with this scenario, in June 2003, the Brazilian National Congress approved the bill by the then President Luiz Inacio Lula da Silva, establishing the National Secretariat of Solidarity Economy (SENAES) in the ambit of the Ministry of Labor and Employment (MTE). The Brazilian Government thus recognized an ongoing process of social transformation, caused by the severe employment crisis that has affected the country since the 1980s. The deindustrialization, which caused the loss of millions of jobs, the opening of the marked that toughened global competition and derived mass wage crushing; massive and long-term unemployment caused the casualization of the employment relationships. These facts have affected a number of countries. (SINGER, 2004)

Singer (2006) also reveals that SENAES was established by law and installed under the demand of the then Solidarity Economy Task Force of the World Social Forum. The Federal Government decision of establishing the National Secretariat of Solidarity Economy, positively 
responding to the mobilizations that occurred in the solidarity economy field (seminars, plenaries, forums), means a dramatic change in labor and employment public policies that aim at income generation and at ensuring the citizen rights of the less favored population in society. The other forms of associated and cooperative work gained momentum and recognition along with other job-generation policies.

Beyond the employment initiatives and of protection to wage labor, the Ministry of Labor and Employment started to take on the challenge of implementing policies that include other forms of organization in the labor world and foster the extension of rights to the set of workers. SENAES collaborates with the mission of the Ministry of Labor and Employment, fostering and supporting the Solidarity Economy Enterprises by means of direct actions or by means of cooperation and agreements with other (federal, state and municipal) government agencies and civil society organizations acting with solidarity economy.

The Report on the Assessment of the Public Policy for Solidarity Economy, elaborated by SENAES (2012), highlights that in June 2003, the enforcement of Law number 10,683, of May 28, 2003, and based on Decree number 4,764, of June 24, 2003, established the National Secretariat of Solidarity Economy (SENAES) and the National Council for Solidarity Economy (CNES). On the same day SENAES was established, the "3rd Plenary on Solidarity Economy" was being held in Brasilia, in which the then Brazilian Forum of Solidarity Economy (FBES) was founded.

Valmor Schiochet (2012) reports that between 2003 and 2010, 435 projects were supported in a partnership with the Bank of Brazil Foundation, connected to the bank of the same name, which works as a not-for-profit institution and has greatly supported the execution of projects in the social area. Another great partner of Solidarity Economy is the Brazilian Innovation Agency (FINEP), subordinated to the Ministry of Science and Technology. It has partnered the program of incubators, of social technology and in the mapping of Solidarity Economy. The direct action of SENAES occurs by means of agreements. The box as follows presents the distribution of participation regarding the resources of these partnerships. A large number of projects approved is from the Bank of Brazil Foundation, although SENAES presents a percentual investment of about $63 \%$ of the resources.

In total, 435 projects to support and to strengthen ES were funded, 146 of which directly by SENAES, 175 by the Bank of Brazil Foundation, 64 by FINEP and 50 by the Banco do Nordeste. The total investment reaches R $\$ 206,278,341.41$ (two hundred and six million, two hundred and seventy eight thousand, three hundred and forty-one reais and forty-one cents).

Singer (2009) highlights that ever since the beginning of its implementation, SENAES has offered courses on solidarity economy to officers of the federal government, not only in Brasília, but also in the agencies located in the states of the federation. When registrations opened, the number of people interested very often exceeded the number of places provided, which usually led to opening new groups. The courses were offered to practically all the targeted ministries, those of the MTE itself standing out, including those given at the Regional Labor Authorities in the states (currently Regional Superintendencies), of the Psychosocial Care Centers of the Ministry of Health (MS), of the 
Popular Educators in activity in Fome Zero (Zero Hunger) and in the Luz para Todos (Electric Power for All).

After the impeachment of President Dilma in 2016, a steady decline was verified in the policy for promoting solidarity economy in Brazil. In Michel Temer's presidential term, started in 2016 deriving from the impeachment, SENAES was transformed into a subsecretariat under the MTE, no longer having the Ministry status.

In Jair Bolsonaro's term, from a subsecretariat, it was made into a department, under the Ministry of Citizenship, once the very Ministry of Labor and Employment was also extinct.

As from 2016, the Brazilian government ceased to adopt an ideology directed to valuing workers and social minorities, consistent with the discourses and social policies developed by the Lula and Dilma governments, and started to act in a declaredly liberal manner, with clear inverse movements to workers' rights, to social movements and, by extension, to the policy for promoting solidarity economy. In its proposal, solidarity economy contemplates a real change in paradigms, which significantly and sumptuously counterposed the liberal model. In the next chapter, concepts and perceptions about empowerment are analyzed, focusing on women empowerment, with a view to relate them to the idea of solidarity economy.

\section{Solidarity economy and empowerment}

It is worth noting the potential of solidarity economy to organize unstructured segments (be it for lack of education or for lack of resources) besides empowering the associates, making them more aware of the logic in which they are inserted, of their rights and duties as citizens and of the need of breaking with individualism, which is characteristic of the capitalist system.

For the UN Mulheres Brasil (2017 Brazil Women), empowerment means to give or acquire power or further power. It means an expansion in the freedom of choosing and acting; that is, an increase in individuals' authority and power over the resources and over the decisions affecting their lives. Empowered people can define their objectives, acquire competencies (or have their own competencies and knowledge recognized), solve problems and provide their own maintenance. It is simultaneously a process and an end. We therefore discuss the empowerment of people in poverty situation, of women, of black people, of indigenous people and of all those experiencing subordination relationships or that are socially underprivileged.

When analyzing the origin of the term empowerment, Sandenberg (2006) highlights that, despite the radical origins of the concept of empowerment, it evolved from "praxis" to "theory", being firstly used by feminist activists and by base movements and only then turning into a theorization object. The author points out that that the concept was taken to the academia, gaining momentum in the feminist perspectives on "power" and, in turn, it was also appropriated by the discourses on "development". In this process, it lost much of its more radical connotations and was therefore seen with mistrust by the 
feminists not familiar with its radical origins.

Equally interesting is the concept presented by Lopez-Claros and Zahidi (2005), in the World Economic Forum, who state that political empowerment regards not only the equitable representation of women in decision-making structures, both formal and informal, but also their right to participate in the formulation of policies that affect the society in which they are inserted.

When defining empowerment from a feminist viewpoint, Sandenberg (2006) states it is simultaneously the process and the result of this process, being that, in the case of women, this process aims to: question the patriarchal ideology; transform the structures and institutions that reinforce and perpetuate gender discrimination and social inequalities; and create the conditions for por women to have access and control over material and informational resources.

For us, feminists, women empowerment is the process for conquering autonomy, self-determination. For us, it is concurrently an instrument/ means and an end in itself. Women empowerment, for us, implies liberating women from the ties of gender oppression, of patriarchal domination. For Latin-American feminists, particularly, the major objective of women empowerment is questioning, destabilizing and, lastly, putting an end to the patriarchal order that supports gender oppression. This does not mean that we do not also want to put an end too poverty, to wars, etc. Yet for us, the major objective of "empowerment" is to destroy the current patriarchal order in contemporary societies, besides taking greater control over "our bodies, our lives". (SANDENBERG, 2006, p. 2, free translation)

This thought is supported by Cruz, Nascimento and Santana (2018), who state that the gender relationships in the patriarchal society are part of the social dynamic of inequalities, which can derive from the so-called 'natural' differences socially built between the male and female genders. A hierarchy is installed as an organizing form of the classifying models, as a way of organizing the world based on the principle of the value that confers significance to the differences of distinct gender values. It is necessary to be alert to the weight of the patriarchal culture that may pose greater or fewer hindrances (asymmetries and segmentation of the market, of sectors and jobs, sexual division of labor) to the access of women to the public sphere and to the labor market.

If the driving power of capitalist economy is profit and competition, in solidarity economy, the logic is markedly different. The great drivers of this economic alternative are solidarity and the spirit of cooperation. Solidarity economy has gradually expanded, and this expansion represents a "light at the end of the tunnel" amidst so much chaos, poverty, inequality and exclusion imposed by capitalism and its mechanisms for perpetuating oppression.. 


\section{Women of Alto Cajari: empowerment by solidarity economy}

The Association of Agricultural-Extractivist Women of Alto Cajari (AMAC) is an enterprise organized by the initiative of the women of the Extractivist Reserve of Cajari and of women from nearby localities that, by means of meetings, were integrated and discussed the importance of uniting, especially for their living in an isolated area.

The Extractivist Reserve of Cajari (RESEX-CA) is a conservation unit of sustainable use established by Decree 99,145, of March 12, 1990, managed by the Chico Mendes Institute for Biodiversity Conservation (ICMBIO), has relevant natural characteristics and firstly represents a historical achievement of the traditional extractivist populations of southern Amapá. According to IBGE (2013), the Cajari RESEX has 4,164 inhabitants.

Its basic objectives are to protect the livelihood and the culture of the populations, ensuring the sustainable use of a parcel of its natural resources in a total area of 501,771 hectares (FREITAS, 2013). This area encompasses the municipalities of Mazagão, Laranjal and Vitória do Jarí.

The Association of Women of the Upper Extractivist Reserve of Cajari was established aiming to generate income and jobs to its associates, who currently work on the processing of Brazilian nut, and collectively produce biscuits, chocolates, sweets and paçoca (sweet made from crushed nut) from Brazilian nut.

\section{Origin and evolution}

The experience led to the beginning of raising the women's awareness about the importance of the organization. After five years in existence of the association, the Brazilian-nut women retake the discussion supported by the Extractivist Association of the Cajari River Reserve (ASTEX-CA), locally known as the association of men and women. They thus created a new association, which started to be managed by the women of the Reserve.

The Association of Agricultural-Extractivist Women of Alto Cajari (AMAC), according to its Social By-Laws, was established on May 8, 2004, with 35 founding associates and, in 2006 comprehended nine communities, out of the thirteen in existence in the upper RESEX Cajari. Its By-Laws is based on the conservation and balance of natural resources and of its ecosystems, so as to ensure sustainable exploitation by the traditional populations in order to achieve the ecological balance of any other domestic activity that comes to emerge in the region, also aiming at the cultural and socioeconomic improvement of its associates.

As from 2009, the AMAC women have directed their activities to producing biscuits and sweets from Brazilian nut, manufactured in an increasingly larger scale. Nut processing was the alternative found by AMAC that fits the local reality and needs. Thereafter, AMAC started to participate in bidding notices of the State of Amapá Government, allowing the transformation of the meeting place, which formerly worked precariously, into a communitarian industrial kitchen, with adequate office space. 
AMAC has 240 associates, distributed into the 13 communities of the Upper RESEX Cajari, among which 12 are located in the Jari Valley area and a single one in the Mazagão municipality. The work by the AMAC associates starts within the forest, in the plantation or in the placements; they collect the nut from the forest, break the hedgehog (ouriço - a large protective shell holding a set of nuts) and store the nuts in regional packaging, produced by the women themselves. Each woman brings an established quantity of nut and of banana to the AMAC kitchen. The other ingredients, such as sugar, butter and wheat flour are collectively purchased by the group; the sum of the total value of the purchase is divided to be paid by the associates.

\section{The Solidarity Economy Enterprise}

The main idea was to gather talents and build a business that transformed the raw material available, especially the Brazilian nut, into products that yielded benefits to all the women at the same time. For this, it was necessary to have premises exclusive to the Association; hence, after its establishment and legalization, the Association was granted with the construction of its Headquarters, after an agreement celebrated with the State of Amapá Government, by means of the State Secretariat of Industry and Commerce (SEICOM) and the State Secretariat of Infrastructure (SEINF).

The Association Headquarters is about $150 \mathrm{~m}^{2}$, counting on a basic structure and two rooms (conceived to hold a production sector), two kitchens, a salon and two lavatories. It has no infrastructure of tables, chairs or other utensils that favor the conduction of any activity in the place, or even for holding institution meetings or assemblies, which occur every three months. The external view of the headquarters is depicted in Figure 1.

\section{Figure 1: AMAC Headquarters}

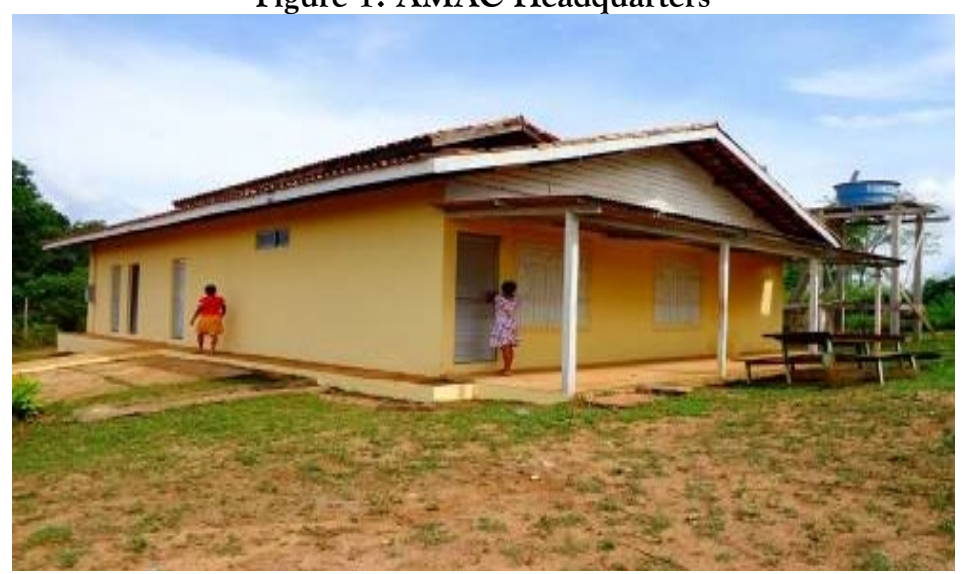

Source: Ribeiro and Filocreão (2013).

The main activity of the associates is manufacturing biscuits, artisanal chocolates, paçocas (sweet made of crushed nuts), sweets, cakes and bread made with Brazilian nut. 
The food products are sold together with some products of the agricultural activities conducted by the women, such as sweet potato, purple yam (dioscorea trifida), oranges, bananas and Brazilian nut - both shelled and unshelled.

The communitarian kitchen was a great achievement for the Brazilian-nut women, representing the confirmation that the organization was climbing to an important stage in the improvement of these women's lives and those of their families. Later, through AMAC, a group of women had access to the rural credit of the National Institute for Colonization and Agrarian Reform - INCRA, the Support to Women, which allowed building the Popular Market of Água Branca do Cajari community, bordering the BR 156 road, where women daily trade their production. (RIBEIRO; FILOCREÃO, 2013)

The commercialization is conducted individually by each associate, but they expect to commercialize collectively, in order to favor all the associates, also with the purpose of improving their quality of life. The sales may come to be conducted directly in stores, street markets or schools, as a source of school meals.

\section{Results and challenges of the enterprise}

For accessing the information regarding the results, impasses and challenges faced by AMAC, interviews were made with the president of the association, who has held the position since 2009, and four other associates that work in the commercialization of products deriving from the nut in the Agricultural-Extractivist Women of Alto Cajari Market.

The access to the Reserve alone is quite a challenge; although it is not that far from Macapá (the capital of Amapá), about $220 \mathrm{Km}$, the road is unpaved, which greatly hinders access, which is even more difficult in rainy days. This challenge was faced for conducting the present research, in a seven-hour trip by bus, starting from the Macapá Bus Station.

The Association comprises 240 women from 13 different communities, 12 being from the Vale do Jari region, and one from the Mazagão municipality, the Sororoca Community.

The president of the Association has not finished her secondary education, is an extractivist and a small farmer, and points out that when she took on the Association in 2009, she was very unsure and lacked orientation as regards the conduction of the activities. She states that what helped her improve her management were the contacts made, and guidance she has received over time. It is worth highlighting that she exerts an effective leadership among the associates, and her management has been greatly acknowledged by the associates. Box 1 synthesizes the social profile of the three associates interviewed besides that of the president at the time of the field research. 
Box 1: Profile of the interviewees - AMAC

\begin{tabular}{|c|c|}
\hline Information & Responses \\
\hline Age & Between 18 and 37 years old. \\
\hline Education & $\begin{array}{l}\text { The president and two interviewees declared to be } \\
\text { taking secondary school, and one interviewee has not } \\
\text { completed her basic education. }\end{array}$ \\
\hline Job/occupation & $\begin{array}{l}\text { The four interviewees are confectioners and commer- } \\
\text { cialize their production in the Women Market. The } \\
\text { president of the Association declared to also be a small } \\
\text { farmer. }\end{array}$ \\
\hline $\begin{array}{l}\text { Number of people residing in the } \\
\text { house the person lives in }\end{array}$ & From 3 to 6 people in general. \\
\hline $\begin{array}{l}\text { The number of people from the } \\
\text { household with a job }\end{array}$ & $\begin{array}{l}\text { The four interviewees reported to work, as do their } \\
\text { husbands; two people in the household work. }\end{array}$ \\
\hline $\begin{array}{l}\text { Beneficiary of the minimum income } \\
\text { program }\end{array}$ & $\begin{array}{l}\text { All the interviewees are aided by the Green Grant } \\
\text { program. They reported to be paid either by the state } \\
\text { program "Renda Para Viver Melhor" (State of Amapa - } \\
\text { Income for a Better Life) or also by the federal program } \\
\text { "Bolsa Família" (federal). }\end{array}$ \\
\hline Family situation & $\begin{array}{l}\text { All the interviewees stated to contribute to the family } \\
\text { income. }\end{array}$ \\
\hline Family income & $\begin{array}{l}\text { The interviewees reported to have an average monthly } \\
\text { income of } \mathrm{R} \$ 1,000.00 \text { to } \mathrm{R} \$ 1,500.00 \text {. }\end{array}$ \\
\hline
\end{tabular}

Source: Elaborated by the author.

The Green Grant Program is a Federal Government cash transfer program under the responsibility of the Ministry for the Environment, which is incumbent with defining the conditions and complementary standards of the program: situation of the benefit, changes in values, granting and cancellation. The Caixa Econômica Bank is the agent operating the Program. (CAIXA ECONÔMICA FEDERAL, 2019)

The program is directed to families in state of extreme poverty, registered in the Federal Government Single Registry for Social Programs and that conduct activities of environmental conservation in the following areas: national forests, federal extractivist reserves and federal sustainable development reserves; forest settlement projects, agricultural-extractivist settlement projects established by INCRA; territories occupied by riverside populations, extractivist, indigenous populations, quilombolas (descendants of escaped slaves who established settlements - quilombos) and other traditional communities; and other rural areas defined as priorities by an Act of the Executive Power.

Bolsa Família is the minimum income program of the Brazilian Federal Government that aims at the direct transfer of income directed to families living in a state of poverty and of extreme poverty all over Brazil, as a way of trying to overcome the state of vulnerability and poverty. Extremely poor families are those with a monthly income of up to R\$ 
89.00 per person and the poor ones are those with a monthly income of between $\mathrm{R} \$ 89.01$ and $\mathrm{R} \$ 178.00$ per person. Provided they are composed of pregnant women and children or adolescents between 0 and 17 years old, for the families participating in the program, the value of each benefit is $R \$ 41.00$ and each family can accumulate up to 5 benefits per month, reaching $\mathrm{R} \$ 205.00$. The program seeks to ensure the right to nourishment, access to education and to healthcare. (CAIXA ECONÔMICA FEDERAL, 2018)

The Income for a Better Life is a minimum income program of the State of Amapá Government, directed to families in a state of social vulnerability and having a monthly per capita income of up to one-fourth of the minimum wage in force and composed of children and adolescents from 0 to 15 years of age. Implemented by State Law 1,598/2011, the beneficiaries receive a value between $R \$ 272.50$ and $R \$ 311$. This is paid for two years, and may be extended for one more year. In 2020, the State benefited about 4 thousand families, in 16 Amapá municipalities. (SIMS, 2020)

One hundred and four women work in the AMAC industrial kitchen. They conduct activities divided into smaller groups and use the kitchen in shifts during the production period. They arrive at the kitchen at seven o'clock in the morning and leave at five p.m. Interviewee 3 pointed out that:

In the beginning, it was difficult for other women and also for the associates' husbands to join, since they did not believe that this work could generate income or contribute substantially to the family income; many said it was 'a waste of time'. The associates only started to be recognized the moment the enterprise started to yield financial returns, and the women associates started to contribute at home with her own earnings; the family and the communities started to believe that the work at the association could really bring improvements to their lives.

According to the research conducted by Ribeiro and Filocreão (2013), 58 women associates acted in the AMAC industrial kitchen; there was an increase by $79.3 \%$ in the number of women. Concerning the relative comparison to the number of associates, in 2013, AMAC counted on 180 women associates, which represents a 33\% increase, considering that the association currently has 240 associates.

AMAC guides the women associates as regards the social benefits, such as maternity leave and social security, benefits guaranteed by the Brazilian Social Security, in a differentiated regime for rural working women. The Association grants the associates the necessary documents for applying for the maternity aid, pension, among other benefits a working woman can access.

When asked if there is planning for the activity, the president responded positively, stating that a monthly planning of the activities is conducted together with the associates and that the planning is made according to the orders placed to the Association. She highlighted that, likewise, a monthly assessment of the activities is made by means of meetings with the associates. 
The assessment of the national policy of solidarity economy was conducted by the National Information System in Solidarity Economy (SIES), established in 2004. SIES conducted three national mappings for identifying and characterizing the Solidarity Economic Developments (EES) in Brazil. The first survey occurred in 2005, when 14,954 EES were mapped. This survey was complemented in 2007, when 6,905 EES more were mapped. At this first stage, information on a total of 21,859 EES was collected. The third round occurred in 2010-2012, when 11,663 EES more were mapped. (SENAES, 2013).

According to a SENAES report (2012), the ES mapping in Brazil provided visibility to the thousands of existing initiatives and called the attention of local governments to support them and to stimulate them. In turn, the increase in local ES policies also reflects the ES organizational advances in recent years, with the creation of networks and forums that interpellated the very state and municipal public powers regarding the establishment of government structures and, later, the very ES policies.

The president also revealed that the equipment used by the Association is its own. It was made available by the State of Amapá Government, through specific projects in 2010 and 2013, as pointed out in the beginning of this section. She reported that the industrial kitchen of the processing factory is currently equipped with an structure adequate to the associates' activities.

According to the president and to other associates, the products are sold directly to customers, by means of the AMAC Market, located opposite a bus stop with an intense circulation of people, and also to the Municipal Government of Laranjal do Jari, which buys the products deriving from the processed nut to be offered as school meals in municipal schools.

When asked about the difficulty found in selling the products, the president highlighted that the greatest difficulty consists in the lack of certification for the packaging, which is still totally artisanal, and without specification of expiry date or nutritional information, which prevents the Association to outflow its production to large companies. A single member pointed out the low consumer demand, which is certainly determined by the movement of buses that stop there, with a large output of products being observed.

The Association is institutionally registered at SETE and at SEBRAE, highlighting the availability of capacity-building courses on business management, customer service and food manipulation at SEBRAE. However, the Association receives no external assessment of its activities. The president also informed that AMAC was not included in the mapping conducted by SENAES in 2012.

When asked about what has to be improved regarding the promotion granted by the State, the president stated the need of greater support to the Association, especially as regards the adequation of the packaging, which has to be certified by Anvisa for expanding the outflow network along with adding value to the products.

Interviewee 3 stressed the need for greater investment in professional qualification in order to expand the possibilities of the associates actuation; she pointed out that "besides the possibility of having cooking courses, also necessary are courses on information technology, business management techniques, among others". 
Each associate monthly contributed with $\mathrm{R} \$ 2,00$ (two reais), a contribution that, according to the president, is insufficient to afford the expenses of the Association, which includes paying for a driver, an accountant and a lawyer that are hired for temporary services. The expenses are partly paid by the surplus of the Factory, the rest being equally shared among the associates working in the factory, 106 women.

The four associates interviewed emphasized that the money deriving from the activities is enough to afford personal expenses, and a surplus is left for other ends. When asked about the major achievements made possible by the Association, the president stressed the group integration, as well as the system to conduct the activities; the actions are planned by the associates themselves, and do not emerge randomly. As a positive aspect, the associates interviewed highlighted the friendships built along the process and the learning acquired.

As regards the challenges surrounding the Association, the president emphasized the need for modernizing and acquiring some machinery, aiming to enhance the production, such as equipment for drying the nut, something still conducted in a handmade fashion, as well as the extraction of the nut oil, which is still not used by AMAC. The president highlighted that some of the Association activities are performed using a very outdated methodology, such as the manual shelling of the nut by the associates, still conducted individually, which demands a long working time.

When questioned about the challenges to AMAC, Interviewee 1 emphasized that "the main mission of AMAC is to keep the integration among the associates, considering the high number of associates and the dynamic of the activities". When asked about what solidarity economy had changed in the lives of the interviewees, the president highlighted the satisfaction brought by the closeness of the group and by the significant advance of the Association, which was shared by the three other associates interviewed.

She also stressed that the Association substantially collaborates to empowering the women associates and that the change in behavior is notorious in the women after the affiliation, since besides having a guaranteed income, they have their self-esteem improved by the co-existence with the associates, by the expansion of their network and by the information they start to have from the dedication to the work.

The Association was verified to have been beneficial to the women associates, since it was clear to see the satisfaction of the interviewees with the results of the enterprise, which allows not only affording the expenses (which are significant, in function of the organizational standard), but there is also a surplus left for different personal ends.

Concerning the cost-effectiveness analysis on the policy directed to promote solidarity economy for the Association, we verified that the State of Amapa provided AMAC with improvement, building the space for the Market and acquiring equipment. However, the associates stress the need for more funding, especially regarding the improvement of packaging, which has to be certified by ANVISA (Brazilian Health Regulatory Agency) to expand the possibilities of outflowing the production.

In this sense, the public policy was considered effective; yet it has to more strongly act towards promoting the addition of value to the product, once the State counts on all 
the conditions to contribute to the process of certifying the biscuits and sweets packaging, which would even more positively impact the commercialization of production and strengthen the Association.

\section{Conclusions}

The globalized and capitalist world tends to adopt similar development standards wherever it goes; it thus despises cultural, social and economic differences, smoothly or blatantly imposing its oppression on those that cannot reach the level of sophistication of the model countries, their form of development being an example to be copied, imitated at any cost, in an ethnocentric process. Being totally insane and unequal, it makes that those that have not reached such level be marked as inferior, lesser or marginal. Actually, the quest for improving the quality of life of the people forming a Country cannot be conceived as a recipe, ready to be applied to whatever the "mold size"; the cultural, historical and socioeconomic differences have to be considered.

The growth of solidarity economy led the State to have to act together with the segment, be it by direct funding, or by follow-up and/or counting of the sector. With this study, the promotion to solidarity economy was analyzed by means of the incentives directed to the Association of Agricultural-Extractivist Women of Alto Cajari (AMAC), that acts in the manufacturing of nut sweets and biscuits.

The organization of the enterprise and the satisfactory results for the associate women entrepreneurs were highlighted. All the interviewees stressed that the income produced by the activities, besides providing for the production expenses, generates resources used for personal purposes. The associates, as well as the president of the Association emphasize their satisfaction with the friendly relationship built, along with the learning acquired.

Standing out among the challenges to the Association is the need for modernization and acquisition of machinery for improving the production. Nevertheless, AMAC showed to be alert to the possibilities of funding and promotion, working on projects of access to approved resources, in values that will provide greater momentum to the activities. The Brazilian-nut women organization has been growing and strengthening. A good example is the establishment of a cooperative directed to expanding production and the outflow of the products, besides consolidating the enterprise in the market.

An important point to be highlighted is the empowerment of women made possible by the participation in the Association. Besides ensuring income, the women have their self-esteem increased by the coexistence with the associates, by expanding their contact network and by the information they started to have while dedicating to the work.

As regards the cost-effectiveness analysis directed to the policy to promote solidarity economy for the Association, it was verified that AMAC was contemplated with an incentive by the State to enhance its enterprise, with improvement, building a space for marketing the products and the acquisition of equipment. However, the interviewees stress the need for further promotion, especially regarding the improvement of the packaging, 
which needs certification for expanding the possibilities to better outflow the production.

In this sense, the public policy was considered effective, yet in need of greater comprehensiveness concerning the promotion destined to adding value to the product. The State has the means, through the State of Amapa Secretariat of Labor and Entrepreneurship (SETE), the State of Amapa Funding Agency (AFAP) and the Institute for Scientific and Technological Research of Amapa (IEPA) and State Secretariat of Health Surveillance (SVS-AP), of contributing to the certification process of the packaging for the biscuits and sweets. This would even more positively impact the commercialization of the production.

This study allowed verifying that policies to promote solidarity economy are hindered by another problem common to other public policies, the precariousness of articulation and integration among the associates, many times caused by problems with communication, for the lack of perception of the State actuation as a complex of different services, which have to work in a harmonious and balanced way, besides the high turnover of posts and strategic functions.

Also standing out is the importance of strengthening the whole, or the sets composing solidarity economy, the set of agents, composed by people, but above all, the set of values, which shows to be as necessary as all the others.

\section{Thanks}

I thank the State University of Amapa (UEAP) for stimulating research and scientific publication, made possible through notices and resolutions for this purpose, as well as the Association of Agroextractive Women of Alto Cajari (AMAC) for their valuable and indispensable collaboration in this study.

\section{References}

CAIXA ECONÔMICA FEDERAL. Bolsa Família. 2018. Disponível em: https://www.caixa.gov. br/programas-sociais/bolsa-familia/Paginas/default.aspx. Acesso em 30/10/2020.

CAIXA ECONÔMICA FEDERAL. Bolsa Verde. 2019. Disponível em: https://www.caixa.gov.br/ poder-publico/infraestrutura-saneamento-mobilidade/meio-ambiente-saneamento/bolsa-verde/ Paginas/default.aspx. Acesso em 25/10/2020.

CRUZ, Maria Helena; NASCIMENTO, Ana Paula L.; SANTANA, Anabela Maurício de. Reflexões sobre o poder mediadas pelo empoderamento das mulheres na condição de sujeito político. INTERthesis. Florianópolis, v.15, n.2, p.38-55 Set.-Dez. 2018. Disponível em: file://C:/ Users/USER/Downloads/55636-Texto\%20do\%20Artigo-201386-3-10-20180913.pdf. Acesso em: 30/10/2020.

FRANÇA FILHO, Genauto Carvalho de.. Terceiro Setor, Economia Social, Economia Solidária e Economia Popular: traçando fronteiras conceituais. Bahia Análise E D Dados. Salvador, SEI - v.2, 
n. 1. P. 09-19. Jun de 2002.

FREITAS, Tito Lívio Pinto de. (2013). A exploração da castanha-do-brasil na Reserva Extrativista do Rio Cajari. Dissertação de Mestrado. Macapá: Universidade Federal do Amapá.

IBGE (Instituto Brasileiro de Geografia e Estatística). Projeto levantamento e classificação do uso da terra. Relatório técnico do uso da terra no Estado do Amapá, 2013. Rio de Janeiro: IBGE.

LOPEZ-CLAROS, Augusto; ZAHIDI, Saadia. Empoderamento das mulheres: Avaliação das disparidades globais de gênero, Fórum Econômico Mundial, 2005. Disponível em: file://C:/Users/ USER/Downloads/empoderamento-das-mulheres--avaliacao-das-disparidades-globais-de-genero---world-economic-forum.pdf. Acesso em 25/10/2020.

ONU MULHERES BRASIL. Princípio de empoderamento das mulheres. 2017. Disponível em: http:// www.onumulheres.org.br/wp-content/uploads/2016/04/cartilha_ONU_Mulheres_Nov2017_digital.pdf. Acesso em 20/10/2020.

RIBEIRO, Karina Nymara Brito; FILOCREÃO, Antonio Sérgio Monteiro. Desafios na Amazônia Brasileira: a organização de mulheres na Reserva Extrativista no Rio Cajari no Amapá. XIX CONGRESSO LATINOAMERICANO DE SOCIOLOGIA - ALAS 29 de setembro a 4 de outubro de 2013, FACSO, Chile-Santiago, 2013.

SARDENBERG, M. B. Cecília. Conceituando "Empoderamento" na Perspectiva Feminista. 2006. 12 f. Artigo - NEIM/UFBA, Bahia, 2006. Disponível em: https://repositorio.ufba.br/ri/bitstream/ ri/6848/1/Conceituando\%20Empoderamento\%20na\%20Perspectiva\%20Feminista.pdf. Acesso em $28 / 10 / 2020$.

SCHIOCHET, Valmor. A experiência da Secretaria Nacional de Economia Solidária: um breve relato. In: LIANZA, Sidney; HENRIQUES, Flávio Chedid (orgs.). A economia solidária na América Latina: realidades nacionais e políticas públicas. Rio de Janeiro: Pró Reitoria de Extensão UFRJ, 2012.

SENAES (Secretaria Nacional de Economia Solidária). Por uma Política Pública Nacional de Formação em Economia Solidária - PPNFES. 2012. Disponível em: http://www.fbes.org.br/biblioteca22/politica_formacao.pdf. Acesso em: 28 mar. 2020.

SENAES (Secretaria Nacional de Economia Solidária). Política Pública Nacional de Formação em Economia Solidária. 2013. Disponível em: http://portal.mte.gov.br/data/files/FF80808148EC2E5E014A394E2F856F5C/Acontece\%20SENAES\%202013\%20-\%20n34\%20ed\%20especial.pdf. Acesso em: 28 jul. 2020.

SIMS (Secretaria de Inclusão e Mobilização Social do Amapá). Programa Renda para Viver Melhor. 2020. Disponível em: https://sims.portal.ap.gov.br/conteudo/servicos/renda-para-viver-melhor. Acesso em 30/10/2020.

SINGER, Paul. Economia solidária no Brasil: Possibilidades e limites. São Paulo: IPEA - Revista Mercado de Trabalho, 2004. 
SINGER, Paul. SENAES: Uma experiência brasileira de política de economia solidária. In: FRANÇA FILHO, Genauto Carvalho et al (Orgs.). Ação pública e economia solidária: uma perspectiva internacional. Porto Alegre: Ed. da UFRGS, 2006. p. 201-206.

SINGER, Paul. Economia Solidária. Entrevista concedida a Paulo de Salles Oliveira. Projetos coletivos de mudança de vida. São Paulo, Edusp/Fapesp, no dia 23 de setembro de 2007. Estudos Avançados, 2008. Disponível em: http://www.scielo.br/pdf/ea/v22n62/a20v2262.pdf. Acesso em: 27/05/2018.

SINGER, Paul. Polícias Públicas da Secretaria Nacional de Economia Solidária do Ministério de Trabalho e Emprego. Revista IPEA: Mercado de Trabalho, maio de 2009.

SINGER, Paul. Os oito primeiros anos da Secretaria Nacional de Economia Solidária. In: LIANZA, Sidney; HENRIQUES, Flávio Chedid (orgs.) A economia solidária na América Latina: realidades nacionais e políticas públicas. Rio de Janeiro: Pró Reitoria de Extensão UFRJ, 2012. 
Kátia Paulino dos Santos

$\checkmark$ katia.santos@ueap.edu.br

ORCiD: https://orcid.org/0000-0002-0216-2228
Submitted on: $18 / 05 / 2020$

Accepted on: 24/05/2021

2021;24e:00661

How to cite: SANTOS, K. P. The women of castanha do Alto Cajari: empowerment by the solidarity economy. . Ambiente \& Sociedade. São Paulo, v. 24, p. 1-18, 2021. 


\title{
As mulheres da Castanha do Alto Cajari: O empoderamento pela economia solidária
}

\author{
Silvia Sayuri Mandai \\ Raphaela Martins de Carvalho \\ Marcelo Marini Pereira de Souza
}

São Paulo. Vol. 24, 2021

Artigo Original
Resumo: Este estudo volta-se a compreender a dinâmica de funcionamento da economia solidária e o processo de empoderamento gerado por ela, por meio da análise da Associação de Mulheres Agroextrativistas do Alto Cajari, localizada no extremo Sul do Amapá, extremo norte do Brasil, que trabalha com o beneficiamento de Castanha do Brasil. Como método, utilizou-se a análise de custo-efetividade e pesquisa qualitativa, no intuito de mensurar os principais avanços e desafios que se impõem ao segmento. Este estudo identificou a necessidade de reestruturação nos formatos de gestão da política de fomento por parte dos órgãos governamentais, os quais deveriam funcionar de forma harmônica e articulada, mas ao contrário disso, atuam de forma isolada e sem comunicação efetiva entre si, prejudicando a qualidade e a quantidade dos serviços ofertados.

Palavras-chave: Economia solidária; empoderamento; Associação de Mulheres Agroextrativistas do Alto Cajari.

Como citar: SANTOS, K. P. As mulheres da castanha do Alto Cajari: o empoderamento pela economia solidária. Ambiente $\mathbb{\&}$ Sociedade. São Paulo, v. 24, p. 1-18, 2021. 


\title{
Las mujeres de la castaña Alto Cajari: el poder de la economía solidaria
}

\author{
Silvia Sayuri Mandai \\ Raphaela Martins de Carvalho \\ Marcelo Marini Pereira de Souza
}

São Paulo. Vol. 24, 2021

Resumen: Este estudio vuelve a comprender la dinámica de funciona-

Artículo original

miento de la economía solidaria y el proceso de empoderamiento que genera, a través del análisis de la Asociación de Mujeres Agroextractivas del Alto Cajari, ubicada en el extremo sur de Amapá, extremo norte de Brasil, que trabaja con el procesamiento de nueces de Brasil. Como método utilizamos el análisis de costo-efectividad y la investigación cualitativa, con el fin de medir los principales avances y desafíos que se imponen al segmento. Este estudio identificó la necesidad de una reestructuración en los formatos de desarrollo de políticas de gestión por parte de las agencias gubernamentales, las cuales deben trabajar de manera armónica y articulada, pero que actúan de manera aislada y sin una comunicación efectiva entre sí, perjudicando la calidad. y la cantidad de servicios ofrecidos.

Palabras-clave: Economía solidaria; empoderamiento; Asociación de Mujeres Agroextractivas Alto Cajari.

Como citar: SANTOS, K. P.. Las mujeres de la castaña Alto Cajari: el poder de la economía solidaria. Ambiente $\mathbb{\&}$ Sociedade. São Paulo, v. 24, p. 1-18, 2021.

DOI: http://dx.doi.org/10.1590/1809-4422asoc20200066r1vu2021L4AO 